\title{
Endophytic fungal diversity of endemic carnivorous plant Nepenthes khasiana in Meghalaya, India
}

\section{Naseem $F$ and Kayang $H$}

Microbial Ecology laboratory, Department of Botany, North Eastern Hill University, Shillong, Meghalaya - 793022, India

Naseem F, Kayang H 2021 - Endophytic fungal diversity of endemic carnivorous plant Nepenthes khasiana in Meghalaya, India. Studies in Fungi 6(1), 138-150, Doi 10.5943/sif/6/1/7

\begin{abstract}
The present investigation deals with the isolation of endophytic fungi from leaf, stem, root and pitcher cup tissue segments of the endemic carnivorous plant Nepenthes khaisana collected from its natural habitat for a period of one year at monthly intervals. Out of 576 tissue segments inoculated, a total of 39 fungal endophytes along with mycelia sterilia were isolated from the host plant. To assess the diversity of fungal endophytes, the colonization frequency $(\% \mathrm{CF})$ was first recorded using past software and MS excel. The fungal isolates were mainly composed of the phylum Ascomycota, followed by Zygomycota and Oomycota. The highest percentage colonization frequency on an average of three replicates were recorded in pitcher cup tissues followed by root, stem and least was recorded in leaf of the host plant. Among the isolates, Globisporangium irregulare $(83.33 \%)$ showed high \% CF in leaf, Juxtiphoma eupyrena (83.33\%) reported to have maximum \% $\mathrm{CF}$ in the stem, Talaromyces ruber $(66.66 \%)$ was recorded high \% $\mathrm{CF}$ in root and mycelia sterilia (white) were showed the highest $\% \mathrm{CF}$ in the segments of leaf. The diversity index analyses of Shannon-Weiner, Simpson's index, species richness and species evenness of diversity showed that leaf of $N$. Khasiana has the highest diversity than the other parts of the plant. So, with the help of the present finding, we conclude that the distribution of fungal endophytes and their \% colonization frequencies vary within different tissues of the host plant and thus, this confirms tissue specificity nature of endophytic fungi.
\end{abstract}

Key words - Colonization frequency - Diversity indices - Natural habitat - Pitcher plant - Tissue specificity

\section{Introduction}

Many ancient literature indicate that synergistic collaboration among fungi and plants have taken place more than 400 million years ago (Krings et al. 2007). Morphologically fungi exist as both microscopic and macroscopic classes. As a result of its existence at the microscopic level, only a few numbers of fungi are recognized and depicted till now. The appellation "Endophytes" has been used in an extensive perception as per its description to comprise bacteria (Kobayashi \& Palumbo 2000), fungi (Petrini 1991, Stone et al. 2000), actinomycetes (Bills et al. 2004, Stone et al. 2000, Tan et al. 2006), algae (Peters 1991) and some insects (Feller 1995) residing within the plant tissues deprived of any ostensible symptoms of the disease. Nearly all type of vascular plants are well-known to harbor endophytic microorganisms (Arnold et al. 2000, Sturz 2000). The ecological condition of the host also influences the endophytic scattering in a population (Hata et al. 1998). Endophytic fungi can enter the plant through its root and colonize different plant parts including 
flowers and fruits as well, but through stomata or wounds in the plant many phyllosphere endophytes can also entre as those wounds or stomata acts as passage to such microorganisms (McCully 2001, Danhorn \& Fuqua 2007, Schulz \& Boyle 2006).

Nepenthes is the tropical carnivorous plant, has been known to have evolutionarily modified leaves as the peripheral digestive organs via leaf epiascidiation process (folding of the leaf towards the interior side with the ventral or upper surface flattering the inside of the pitcher) in order to receive nutrients from prey trapped inside the pitcher cups. For the digestion of the prey, Nepenthes reduces the $\mathrm{pH}$ of its fluid to facilitate the enzymatic reactions and to regulate the bacterial population present in the micro-habitat (Chan et al. 2016).

The present study aimed to isolate endophytic fungi from leaves, stems, roots and pitcher cups of an endemic plant of Meghalaya, $N$. khasiana. It is a carnivorous IUCN listed - endangered plant. $N$. khasiana is the only representative of the family Nepenthaceae from India and is considered to harbor vast range of medicinal properties used in traditional medicine by local people. Thus, the aspect of assessing the diversity of endophytic fungi will help to understand the association of fungal endophytes with the host plant.

\section{Materials and methods}

\section{Sample collection}

For the isolation of endophytic fungi, $N$. khasiana was selected as the host plant. The plants were randomly collected for a period of 1 year (2015-2016) at monthly intervals from the West Jaintia Hills district of Meghalaya. The plants were collected aseptically in sterilized polythene bags which were taken to the laboratory and processed within 24 hours of collection.

\section{Surface sterilization}

The samples were surface sterilized following the slightly modified protocol of Bayman et al. 1997. The plant parts were vigorously washed under running tap water to remove dust and soil particles. The protocol given by Suryanarayanan et al. 1998 (modified) was used for the isolation of endophytic fungi from the sterilized plant samples. Different plant parts (leaves, stems, roots and pitcher cups) of $N$. khasiana were chopped into small fragments of $0.5 \mathrm{~cm}$ diameters. These segments were then surface sterilized by immersing them in $70 \%$ ethanol for 1-3 minute, followed by treatment in $2 \%(\mathrm{v} / \mathrm{v})$ sodium hypochlorite $(\mathrm{NaOCl})$ for 3 minutes, then again immersing them in $70 \%$ ethanol for 30 seconds and then lastly rinsed with sterile distilled water to remove any traces of surface sterilants. The excess moisture adhering to the treated segments were eliminated by blotting with sterilized Whatman No.1 filter paper.

\section{Efficiency of surface sterilization}

The effectiveness of surface sterilization was performed by washing the surface sterilized samples with sterile water few times followed by transferring the samples in $5 \mathrm{ml}$ of sterile water. The sterilized sample-water mixtures thus obtained were then stirred for $1 \mathrm{~min}$. An aliquot of 0.5 $\mathrm{ml}$ water obtained above (after removing the plant parts) was then inoculated on Potato Dextrose Agar (PDA) medium and incubated at $27^{\circ} \mathrm{C}$ for 7 days. Plates which show negative result considered as successfully surface disinfected and the procedure thus used for the isolation of endophytic fungi (Schulz et al. 1993).

\section{Isolation of endophytic fungi}

For the isolation of endophytic fungi, samples were dried under laminar airflow to avoid contamination. Prepared samples were inoculated on to a Petri dish containing PDA (Potato Dextrose Agar) medium amended with Streptomycin $(200 \mathrm{mg} / \mathrm{l})$ to suppress any bacterial growth. The Petri dishes were sealed using Parafilm ${ }^{\mathrm{TM}}$ and incubated at $25 \pm 2^{\circ} \mathrm{C}$ in an incubator for 7 to 15 days. Further to the development of colonies on culture plates were studied by isolating them and again sub-cultured as pure culture on PDA and Czapeck Dox Agar (CDA) media. For characterization of the morphology of fungal isolates, slides were prepared and stained with lacto-phenol blue reagent and examined under a bright field 
microscope. Identification was done by referring standard monographs (Ellis 1976, Domsch et al. 1980, Barnett \& Hunter 1972, Subramanian 1971) and with the help of their morphological characteristics such as growth pattern, hyphal characters, colour of colonies on the medium, surface texture, margin character, aerial mycelium, mechanism of spore production and characteristics of the spores. The isolated fungal endophytes have been deposited to the Microbial Repository Centre (MRC), IBSD, Manipur, India. Culture samples that did not produce any spores were categorized separately and given a code based on colour of mycelium and morphological feature of colony. Molecular characterization (ITS sequence of rDNA) was done to confirm the identification of such sterile fungal strains and the nucleotide sequences obtained in this study were deposited to the NCBI- GenBank database with following accession numbers - MH458928.1, MH458932.1, MH510306.1, MH458934.1 and MH458933.1.Confirmation of the presence of endophytic fungal spores and elongation of new hyphae in different tissue parts of the host plant was performed with the help of Scanning Electron Microscopy (SEM) (Fig. 2).

\section{Data analysis}

With the intention to estimate the diversity of endophytic fungi, the colonization frequency $(\% \mathrm{CF})$ of endophytic fungi was calculated and determined by using the formula given by Hata \& Futai (1995). Dominant endophytes were calculated as percentage of colony frequency of an endophyte divided by the sum of the percentage of colony frequency of all endophytes x100 (Tayung \& Jha 2006).

$$
\mathrm{CF}(\%)=\left(\mathrm{N}_{\mathrm{Col}} / \mathrm{N}_{\mathrm{t}}\right) \times 100
$$

Where, $\mathrm{N}_{\mathrm{Col}}=$ Number of segments of plant tissue colonized by each fungus and $\mathrm{N}_{\mathrm{t}}=$ Total number of segments of plant tissue studied.

The fungal diversity of endophytic population was estimated with the following diversity indices. The reason for using these diversity indices was to take advantage of the strength of each index and to predict the complete structure of the population. All the statistical analyses were achieved with the software package PAST3 and MS Excel (Hammer et al. 2001) following diversity indices were calculated: (a) Simpson's Index. (b) Simpson's index of diversity. (c) Specie richness. (d) Shannon-Weaver diversity index. (e) Evenness was calculated.

(a) Simpson's index (D) was calculated by following formula (Simpson 1951): $D=\Sigma(n / N)^{2}$ Where, $\mathrm{n}=$ Total number of isolates of a particular species and $\mathrm{N}=$ Total number of isolates of all species.

(b) Simpson's index of diversity $=1-\mathrm{D}$ (D is Simpson's index)

Species richness is a measure of the number of species found in a sample. This particular measure of species richness is known the Menhinick's index: (c) Species richness $=\mathrm{S} / \sqrt{\mathrm{N}}$ Where, $\mathrm{S}=$ Total number of species.

Index of general diversity $\left(\mathrm{H}^{\prime}\right)$ or Shannon \& Weaver (1949) diversity (Shannon \& Weaver 1949): (d) Shannon Index $\left(\mathrm{H}^{\prime}\right)=-\Sigma$ pi ln pi

Where, $\mathrm{pi}=\mathrm{n} / \mathrm{N}, \mathrm{n}$ is the total number of isolates of a particular species, $\mathrm{N}=$ Total number of isolates of all species and $\ln =$ Natural Log.

Pielou's evenness J' (Pielou 1995), which is expressed by the Shannon information scaled by the maximum information, to measure species evenness for each community: (e) $J^{\prime}=H^{\prime} / \ln (S)$ Where, $\mathrm{H}^{\prime}=$ Observed value of Shannon index and $\mathrm{S}=$ Total number of species observed.

\section{Results}

During the study period, a total of 576 plant segments (leaves, stems, roots and pitcher cups) 
were plated for the isolation of endophytic fungi. 4 segments per plates were inoculated on PDA medium plates with three replicate each (Fig. 1) and to maintain pure culture, Czapeck dox agar (CDA) medium plates have been used. Highest numbers of fungal endophytes were isolated from the leaf of $N$. khasiana followed by pitcher cup, stem and root for the study period. SEM images also confirm the presence of fungal endophytes within the different plant tissues of the host plant $N$. khasiana (Fig. 2). The fungal isolates were mainly composed of Ascomycota (25 genera; 35 species), followed by Zygomycota (3 genera; 6 species) and Oomycota ( 3 genera; 5 species).

A total of 39 endophytic fungi were isolated and identifies from the different plant parts of $N$. khasiana during the one year of study period. Table 1 depicts the list of endophytic fungi isolated from N. khasiana. Among these isolates, it was observed that the phylum Ascomycota dominated the endophytic assemblage within the host plant. In our study we detected that $61.53 \%$ of isolates belonged to Ascomycota followed by Oomycota, Zygomycota and mycelia sterilia with $12.82 \%$ each. The fungal assemblage was found to be dominated by the class Sordariomycetes (25.64\%) followed by Eurotiomycetes (20.51\%), Dothideomycetes (10.25\%), and Incetraesedis and Mycelia sterilia (12.82\% respectively), Mucoromycetes (7.69\%), Mortierellomycetes (5.12\%), Pezizomycetes and Leotiomycetes $(2.56 \%$ each). Endophytic fungi with maximum average percentage of colonization frequency $(\% \mathrm{CF})$ were considered to be dominant. During the sampling period, Juxtiphoma eupyrena and Talaromyces ruber exhibited highest dominance in the leaf with $15 \%$ each followed by Globisporangium irregulare with $8.33 \%$. The endophytic assemblage in the stem was dominated by Mycelia sterilia white (16.39\%), J. eupyrena (13.66\%) and T. ruber with $12.29 \%$. The dominant root endophytes were MS brown (22.78\%) and T. ruber (10\%). Whereas, in pitcher cup it was dominant by MS white (17.5\%) followed by Colletotrichum gloeosporioides and Gliomastix cerealis with $10 \%$ each.

We found that Alternaria alternata, Fusarium proliferatum, Gongronella butleri and Mortierella sp.1 were isolated only from the leafs, Periconia macrospinosa, Phymatotrichopsis omnivore, Mycelia sterilia (black) and Mycelia sterilia (Red) were specific only to the stem, in root Globisporangium intermedium, Pythium aphanidermatum, Rhizopus microspores, Rhizopus sp. and Scytalidium lignicola were restricted to the root tissues and Cosmospora butyri, Mortierella gamsii, Mortierella sp. 2, Penicillium jensenii and Phytophthora cactorum were isolated only from the pitcher cups. However, Cladosporium cladosporioides, Gliomastix cerealis, Juxtiphoma eupyrena, Penicillium brevicompactum, Talaromyces purpureogenus, T. ruber, T. rugulosus, MS (brown) and Mycelia sterilia (white) were found to be present in all the plant parts of the sampling plant.

In which, Globisporangium irregulare (83.33\%), Penicillium glabrum (66.66\%) and MS white (58.33\%) showed highest percentage of colonization frequency in leaf (Fig. 3). It was found that endophyte $J$. eupyrena $(83.33 \%)$ and Fusarium redolens $(33.33 \%)$ showed maximum \%CF in stem (Fig. 4), Talaromyces ruber (66.66\%), T. purpureogenus and MS (white) with \%CF 58.33\% was maximum in root (Fig. 5). However, C. gloeosporioides and G. cerealis showed \%CF 66.66 in pitcher cup (Fig. 6), where the highest \%CF was recorded by MS (white) with $116.66 \%$.

Shannon index $\left(\mathrm{H}^{\prime}\right)$ was found to be highest in the leaf with the value of 2.78 followed by pitcher cup with 2.76 whereas it was recorded to be the least in root with value of 2.68 , which indicates the vise-versa result for Simpson's diversity index (1-D). Simpson's index of dominance (D) was found to be highest in root with value of 0.09 and $d$ index was least in leaf (0.07). Species richness $(\mathrm{S} / \sqrt{ } \mathrm{N})$ was recorded to be highest in leaf with the value of 2.34 and minimum in leaf with value of 1.64. As like other indices, Species evenness (E) was also recorded and it was found to be highest in leaf with value of 0.96 whereas, it was recorded to be least in root with value of 0.89 (Table 2).

\section{Discussion}

In the present investigation, the endophytic fungi isolated from $N$. khasiana were mainly composed of Ascomycota ( 25 genera; 35 species), followed by Zygomycota ( 3 genera; 6 species) and Oomycota (3 genera; 5 species). However, high percentage of ascomycota as endophytic fungi were also reported by the work of Goveas et al. (2011) from Coscinium fenestratum- a red list 
endangered medicinal plant, it could be due to the ability of Ascomycota to produces ascospores which helps them to strive against other microorganisms through the harsh environmental circumstances. A total of 5 mycelia sterilia were also isolated. The group of mycelia sterilia consists of several morphological fungal varieties, but then again not forming spores under laboratory conditions. This group of fungi is significantly predominant in endophytic studies (Lacap et al. 2003). Other studies on endophytic fungi are also reported the presence of sterile forms in their survey (Suryanarayanan et al. 1998, Rajagopal 1999, Maheswari 2011). Several phylloplane fungi such as Alternaria, Aureobasidium, Cladosporium, Epicoccum belonged to Hyphomycetes were isolated as endophytes from a wide range of plant species growing in different habitats (Bills 1996, Peláez et al. 1996). These phylloplane fungi are proficient of penetrating the outer layers of the leaf or may be confined in the substomatal cavities (Cabral et al. 1993). In our study we also have witnessed similar finding where some of the phylloplane fungi viz. Alternaria, Cladosporium etc. were isolated as fungal endophytes.

In the case of the present investigated plant the endophytic fungi isolated were Gliomastic cerealis, Juxtiphoma eupyrena, Talaromyces purpureogenus, MS (Brown) and MS (white) showed highest colonization ferequency $(\% \mathrm{CF})$ as compared to other isolated of the plant. And among all, J. eupyrena was observed as commonly occurring endophytes in all the plant parts of N. khasiana. Similar occurrence of $J$. eupyrena was observed in the tissues of Artemisia thuscula by Cosoveanu et al. (2018). It was observed that in selected plant for present investigation, the Shannon diversity index $\left(\mathrm{H}^{\prime}\right)$ was higher in the aerial part of the plant i.e. in leaf followed by the underground part (root) and least was observed in stem of the plant, this is the opposite of the previous finding by Jin et al. (2013). However, Simpson's index of dominance (D) showed the vise-versa result. Species richness was also reported to be higher in leaf and lower in roots during the two year of the study period. A smilar finding was reported by various researchers viz. Kumar \& Hyde (2004), Raviraja (2005), Huang et al. (2008), Sun et al. (2008), Xing et al. (2010), Chaeprasert et al. (2010), Thalavaipandian et al. (2011), Siqueira et al. (2011) and Suwannarach et al. (2011). This could be due to the fact that $N$. khasiana is a carnivorous plant that grows in the soil where the nutritional value and $\mathrm{pH}$ of the soil is low and therefore, they adjust their requirements through the captured and digested prey. Moreover, the surface area of leaf is supplementary as compared to the roots of pitcher plants. The time of leaf exposure may also have accounted for the better density of endophytic fungi (Fröhlich et al. 2000, Toofanee \& Dulymamode 2002, Arnold \& Herre 2003). Huang et al. (2008) also pointed out the tissue specific trait of endophytic fungi although most of the endophytes only exhibited tissue preference this partially supports our finding where a higher number of endophytes has been isolated from a specific tissue as compared to other tissues of the host plant.

Table 1 List of fungal endophytes isolated from different plant parts (leaf, stem, root and pitcher cup) of $N$. khasiana during the study period of 2015-2016.

\begin{tabular}{|c|c|c|c|c|c|}
\hline $\begin{array}{l}\text { Sl. } \\
\text { No }\end{array}$ & Endophytic fungal isolates & $\mathbf{L}$ & $\mathbf{S}$ & $\mathbf{R}$ & $\mathbf{P C}$ \\
\hline \multicolumn{6}{|c|}{$\begin{array}{l}\text { Phylum: Ascomycota- } 17 \text { Genera, } 24 \text { Species } \\
\text { Class- Sordariomycetes }\end{array}$} \\
\hline \multicolumn{6}{|c|}{ Order- Hypocereales } \\
\hline 1 & Acremonium murorum (Corda) W. Gams 1971 & + & - & - & + \\
\hline 2 & Cosmospora butyri (J.F.H. Beyma) Gräfenhan, Seifert \& Schroers 2011 & + & - & - & - \\
\hline 3 & Fusarium proliferatum (Matsush.) Nirenberg ex Gerlach \& Nirenberg 1982 & + & - & - & - \\
\hline 4 & F. redolens Wollenw. 1913 & + & + & - & - \\
\hline 5 & Gliomastix cerealis (P. Karst.) C.H. Dickinson 1968 & + & + & + & + \\
\hline & Rectifusarium ventricosum (Appel\&Wollenw.) L. Lombard \&Crous 2015 & - & + & + & - \\
\hline \multicolumn{6}{|c|}{ Order- Sordariales } \\
\hline 1 & Humicola fuscoatra Traaen 1914 & - & + & + & - \\
\hline 2 & Trichocladium griseum (Traaen) X. Wei Wang \& Houbraken 2018 & - & + & + & + \\
\hline
\end{tabular}


Table 1 Continued.

\begin{tabular}{|c|c|c|c|c|c|}
\hline $\begin{array}{l}\text { Sl. } \\
\text { No }\end{array}$ & Endophytic fungal isolates & $\mathbf{L}$ & $\mathbf{S}$ & $\mathbf{R}$ & $\mathbf{P C}$ \\
\hline \multicolumn{6}{|c|}{ Order- Incertaesedis } \\
\hline 1 & Arthrinium arundinis (Corda) Dyko\& B. Sutton 1979 & + & - & - & + \\
\hline \multicolumn{6}{|c|}{ Order- Glomerellales } \\
\hline 1 & Colletotrichum gloeosporioides (Penz.) Penz. \& Sacc. 1884 & + & - & - & + \\
\hline \multicolumn{6}{|c|}{ Class- Dothiodeomycetes } \\
\hline \multicolumn{6}{|c|}{ Order- Pleosporales } \\
\hline 1 & Alternaria alternate (Fr.) Keissl. 1912 & - & + & + & - \\
\hline 2 & $\begin{array}{l}\text { Juxtiphoma eupyrena (Sacc.) Valenz.-Lopez, Crous, Stchigel, Guarro \& } \\
\text { Cano } 2017\end{array}$ & + & + & + & + \\
\hline \multicolumn{6}{|c|}{ Order- Capnodiales } \\
\hline 1 & Cladosporium cladosporioides (Fresen.) G.A. de Vries 1952 & + & + & + & + \\
\hline \multicolumn{6}{|c|}{ Order- Tubeufiales } \\
\hline 1 & Tubeufia cerea (Berk. \& M.A. Curtis) Höhn. 1919 & + & - & + & - \\
\hline \multicolumn{6}{|c|}{ Class- Eurotiomycetes } \\
\hline \multicolumn{6}{|c|}{ Order- Eurotiales } \\
\hline 1 & Penicillium brevicompactum Dierckx 1901 & + & + & + & + \\
\hline 2 & P. glabrum (Wehmer) Westling 1911 & + & - & + & + \\
\hline 3 & P. simplicissimum (Oudem.) Thom 1930 & + & + & + & - \\
\hline 4 & P. jensenii K.W. Zaleski 1927 & - & - & - & + \\
\hline 5 & Talaromyces islandicus (Sopp) Samson, N. Yilmaz, Frisvad \& Seifert 2011 & - & - & - & + \\
\hline 6 & $\begin{array}{l}\text { T. purpureogenus Samson, N. Yilmaz, Houbraken, Spierenb., Seifert, } \\
\text { Peterson, Varga \& Frisvad } 2011\end{array}$ & + & + & + & + \\
\hline 7 & T. ruber (Stoll) N. Yilmaz, Houbraken, Frisvad \& Samson 2012 & + & + & + & + \\
\hline 8 & T. rugulosus (Thom) Samson, N. Yilmaz, Frisvad \& Seifert 2011 & + & + & + & + \\
\hline \multicolumn{6}{|c|}{ Class- Pezizomycetes } \\
\hline \multicolumn{6}{|c|}{ Order- Pezizales } \\
\hline 1 & Phymatotrichopsis omnivore (Duggar) Hennebert 1973 & - & + & - & - \\
\hline \multicolumn{6}{|c|}{ Class- Leotiomycetes } \\
\hline \multicolumn{6}{|c|}{ Order- Incertaesides } \\
\hline 1 & Scytalidium lignicola Pesante 1957 & - & - & + & - \\
\hline \multicolumn{6}{|c|}{ Phylum: Oomycota- 3 Genera, 5 Species } \\
\hline \multicolumn{6}{|c|}{ Class- Incertaesides } \\
\hline \multicolumn{6}{|c|}{ Order- Peronosporales } \\
\hline 1 & Globisporangium intermedium (de Bary) Uzuhashi, Tojo \& Kakish. 2010 & - & - & + & - \\
\hline 2 & G. irregular (Buisman) Uzuhashi, Tojo \& Kakish. 2010 & + & + & + & + \\
\hline 3 & Phytophthora cactorum (Lebert \& Cohn) J. Schröt. 1889 & - & - & - & + \\
\hline 4 & P. cinnamomi Rands 1922 & + & + & - & + \\
\hline 5 & Pythium aphanidermatum (Edson) Fitzp. 1923 & - & - & + & - \\
\hline \multicolumn{6}{|c|}{ Phylum: Zygomycota- 3 Genera, 5 Species } \\
\hline \multicolumn{6}{|c|}{ Class- Mortierellomycetes } \\
\hline \multicolumn{6}{|c|}{ Order- Mortierellales } \\
\hline 1 & Mortierella sp. 1 & + & - & - & - \\
\hline 2 & Mortierella sp. 2 & - & - & - & + \\
\hline \multicolumn{6}{|c|}{ Class- Mucoromycetes } \\
\hline & Mucorales & & & & \\
\hline 1 & Gongronella butleri (Lendn.) Peyronel\& Dal Vesco 1955 & + & - & - & - \\
\hline 2 & Rhizopus microspores Tiegh. 1875 & - & - & + & - \\
\hline 3 & Rhizopus sp. & - & + & - & - \\
\hline & ia sterilia (MS)- 5 isolates & & & & \\
\hline 1 & MS (Black) & - & + & - & - \\
\hline 2 & MS(Brown) & - & + & + & + \\
\hline 3 & MS (Red) & - & + & - & - \\
\hline 4 & MS (White) & + & + & + & + \\
\hline 5 & MS (Yellow) & + & - & + & - \\
\hline & 23 Genera, 34 Species and 5 Mycelia sterilia & & & & \\
\hline
\end{tabular}


$\mathrm{L}=$ leaf, $\mathrm{S}=$ stem, $\mathrm{R}=$ root, $\mathrm{PC}=$ pitcher cup, ' + ' = present and '-' = absent

Table 2 Diversity indices of fungal endophytes isolated from $N$. khasiana during the study period of 2015-2016.

\begin{tabular}{llllll}
\hline Plant tissue & $\begin{array}{l}\text { Shannon } \\
\text { index (H') }\end{array}$ & $\begin{array}{l}\text { Simpson's index } \\
\text { of Dominance (D) }\end{array}$ & $\begin{array}{l}\text { Simpson,s diversity } \\
\text { index (1-D) }\end{array}$ & $\begin{array}{l}\text { Species richness } \\
\text { (S/ } / \mathbf{N})\end{array}$ & $\begin{array}{l}\text { Species } \\
\text { evenness (E) }\end{array}$ \\
\hline Leaf & 2.78 & 0.07 & 0.92 & 1.64 & 0.96 \\
Stem & 2.68 & 0.08 & 0.91 & 2.07 & 0.92 \\
Root & 2.68 & 0.09 & 0.90 & 2.26 & 0.89 \\
Pitcher cup & 2.76 & 0.07 & 0.90 & 2.34 & 0.90 \\
\hline
\end{tabular}

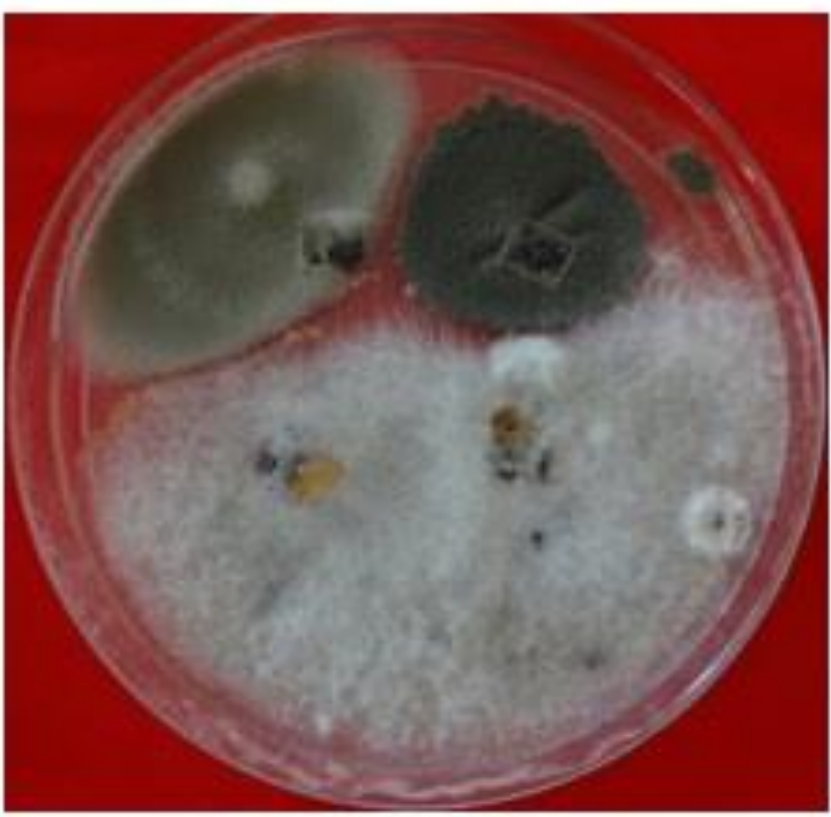

(a)

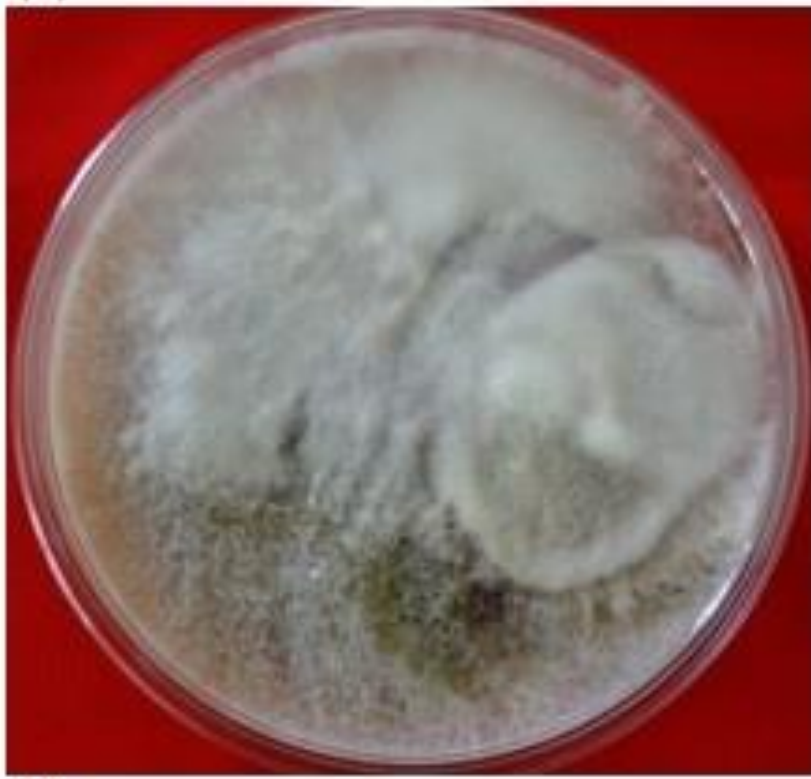

(c)

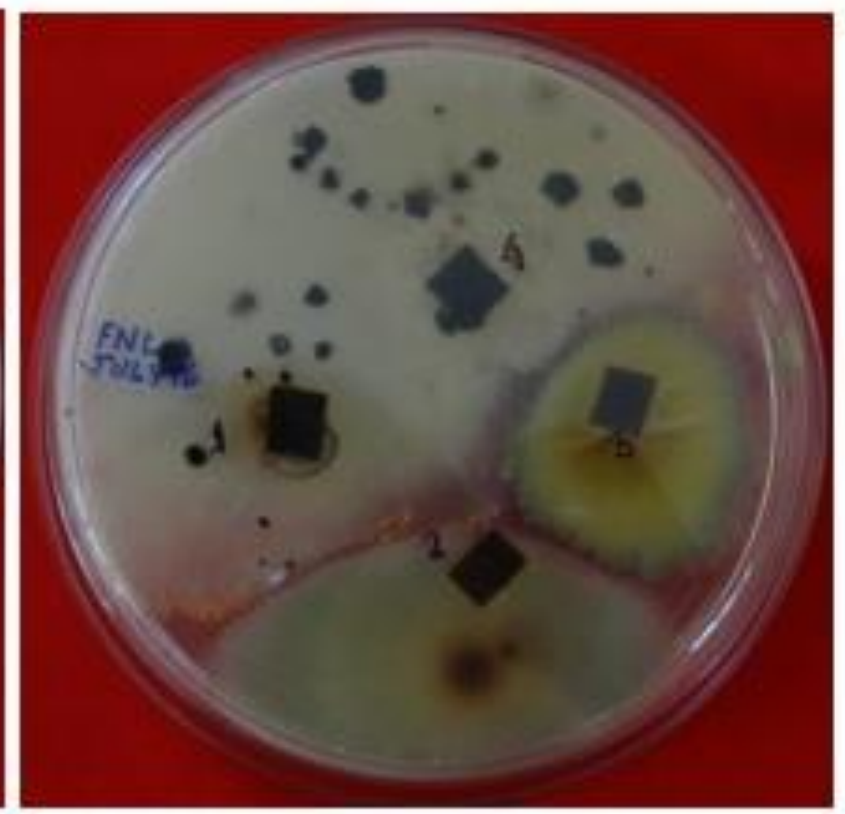

(b)

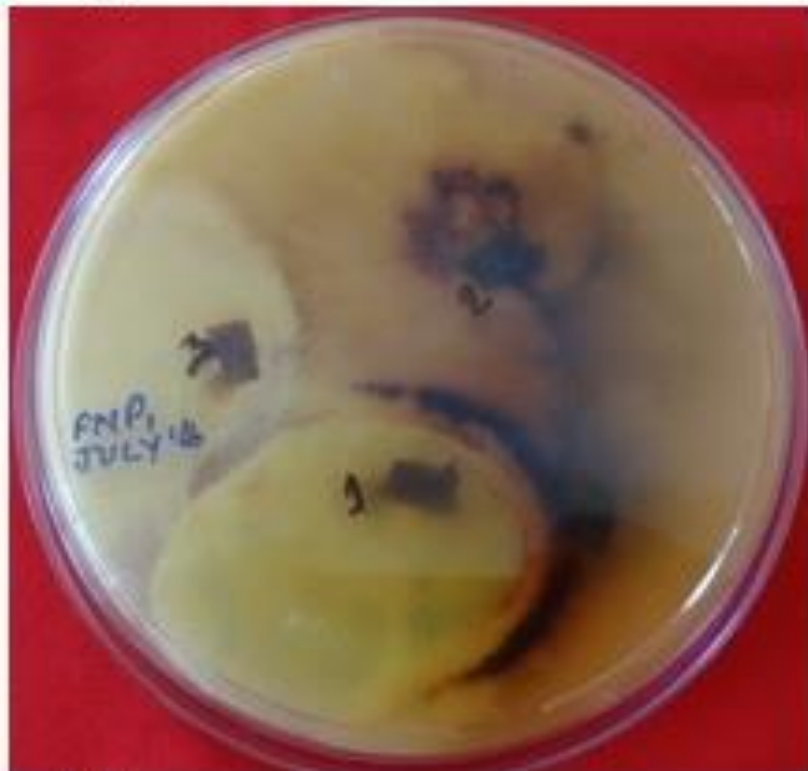

(d)

Fig. 1 - Plates showing mix cultures of fungal endophytes isolated from different plant parts of N. khasiana. 


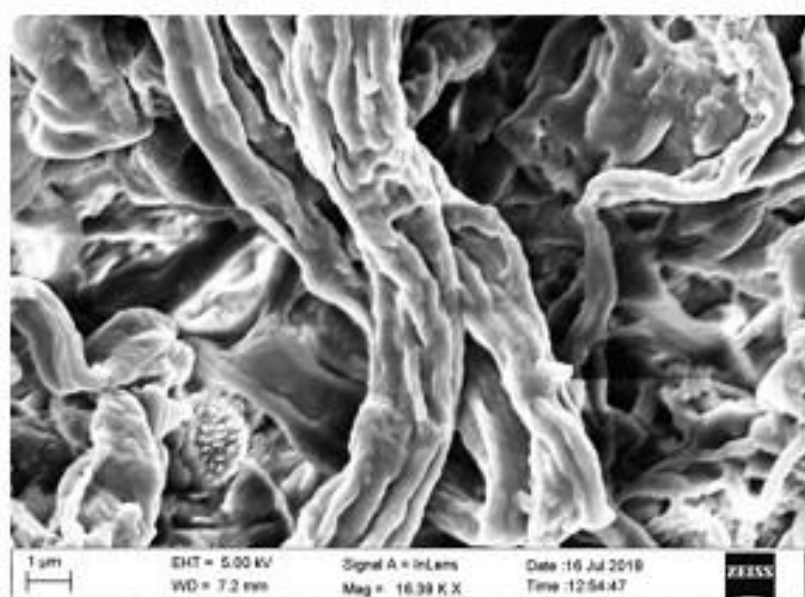

(a)

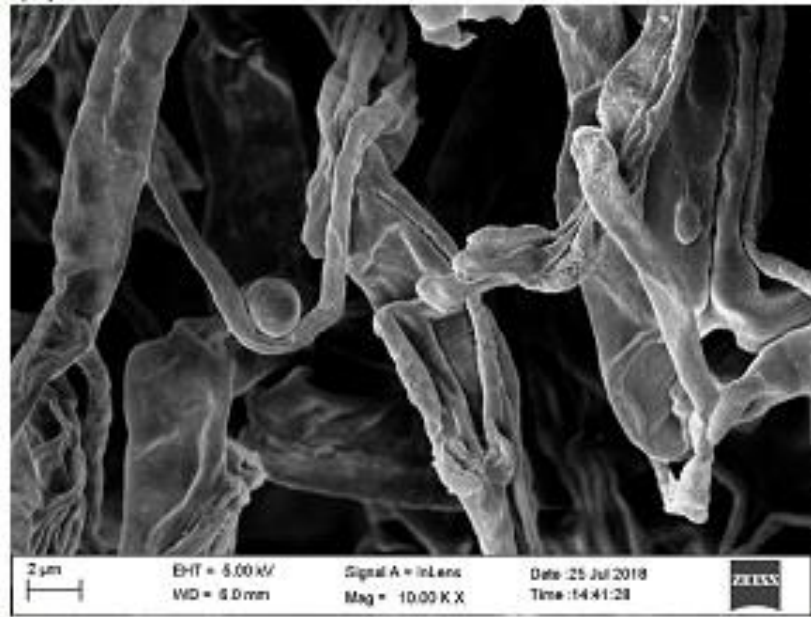

(c)

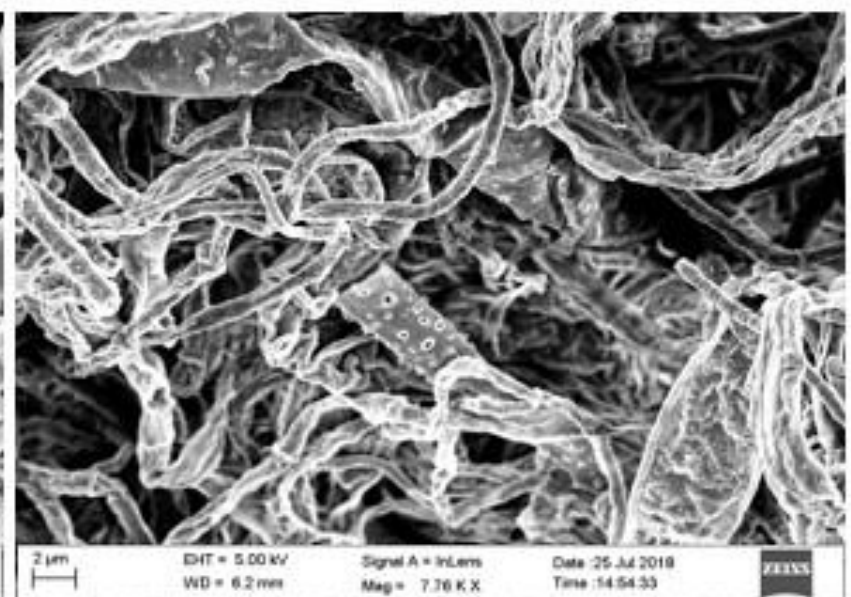

(b)

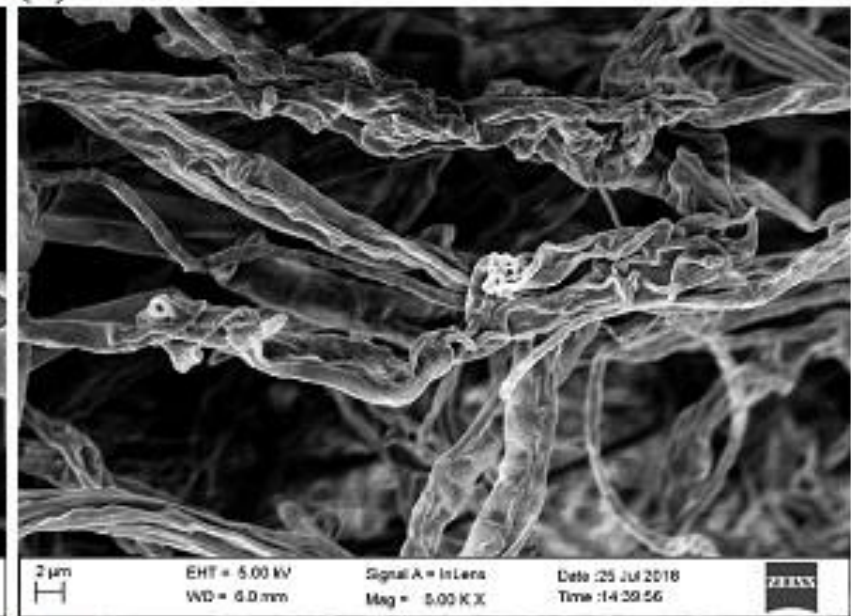

(d)

Fig. 2 - SEM micrograph showing the presence of endophytic fungal spore in (a) leaf and (b) stem; the elongation of new hyphae from mycelia of fungal endophytes in (c) root and (d) pitcher cup.
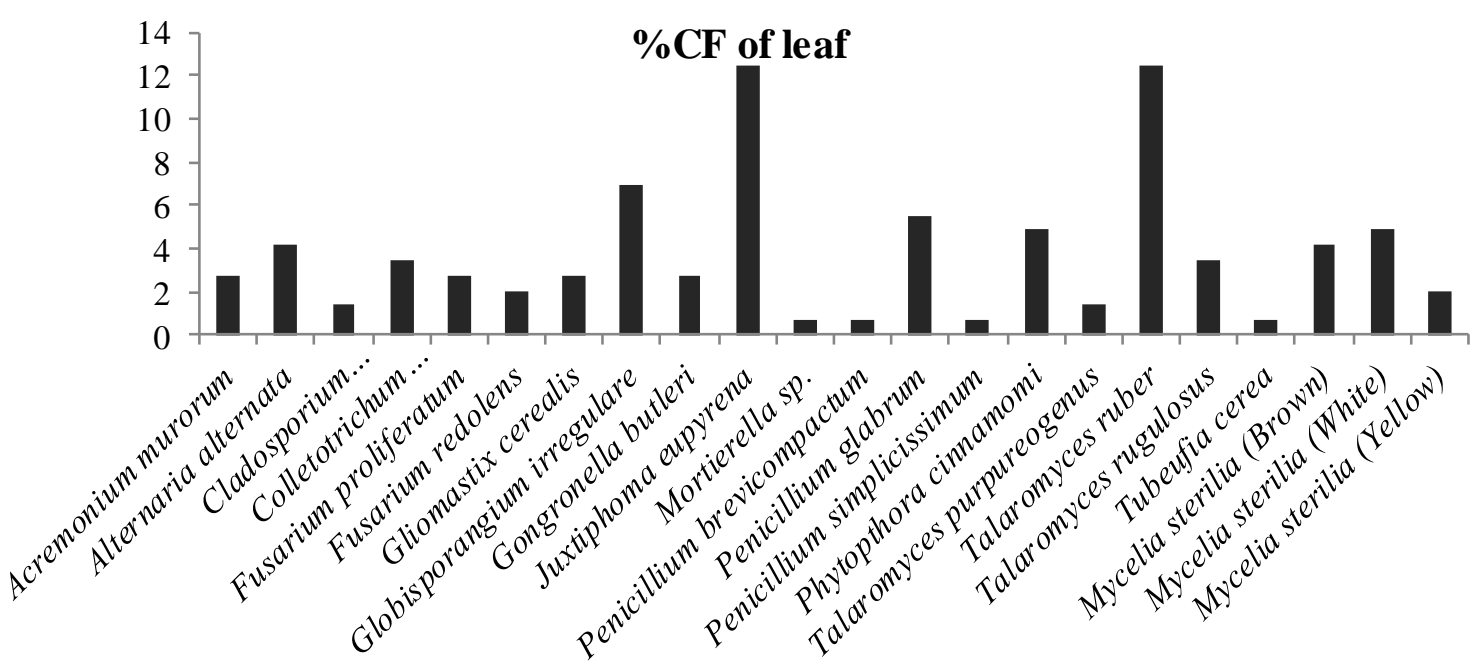

Fig. 3 - Percentage colonization frequency of endophytic fungi isolated from the leafs of $N$. khasiana during the study period of 2015-2016 


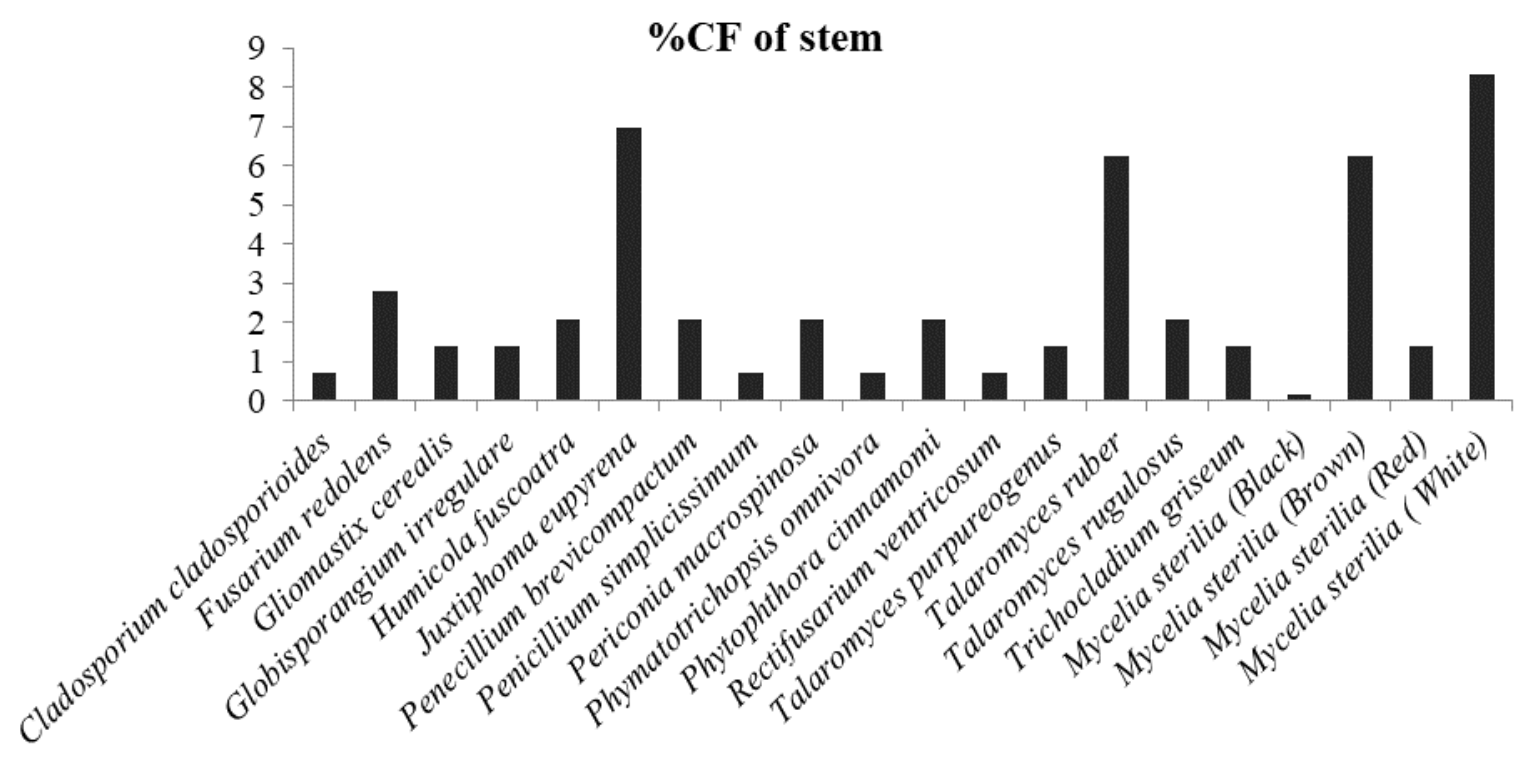

Fig. 4 - Percentage colonization frequency of endophytic fungi isolated from the stem of $N$. khasiana during the study period of 2015-2016

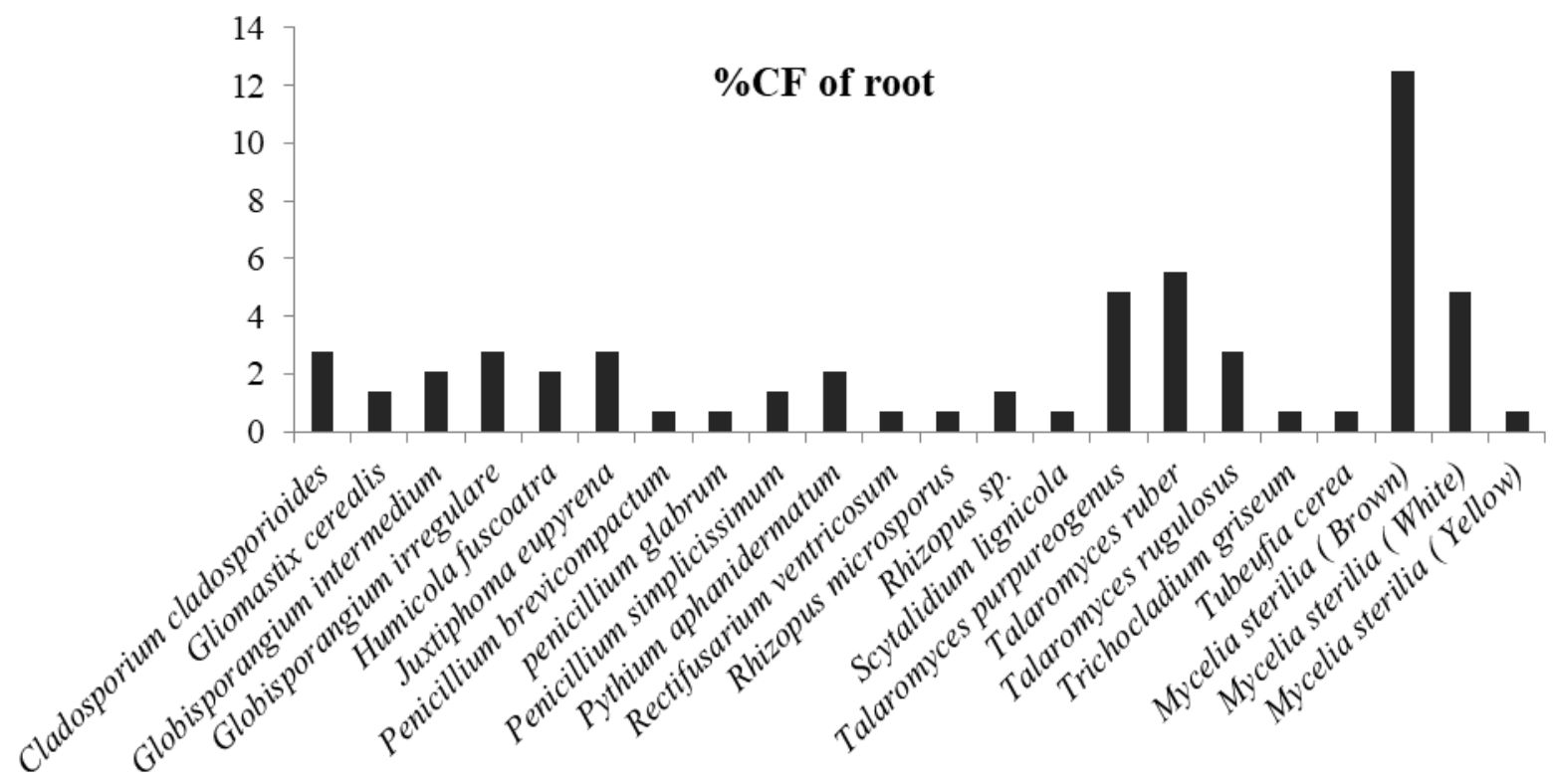

Fig. 5 - Percentage colonization frequency of endophytic fungi isolated from the root of $N$. khasiana during the study period of 2015-2016

\section{Conclusion}

From the present investigation, it can be concluded that the carnivorous plant Nepenthes khasiana, which is one of the endemic plants of the north-eastern state of Meghalaya, India, harbor a great diversity of endophytic fungi. The colonization frequency of the isolates from different tissues of the host plant significantly differed between leaf, stem, root and pitcher cup. Hence, this entire study can be considered as an earnest attempt in exploring the diversity of fungal endophyte and their association with the pitcher plant, and therefore, the further study to explore the facts that how these fungal endophytes are helping the plant in the digestion of prey, synthesis of several secondary metabolites, endurance towards the harsh environment, etc. is 
much needed. Additionally, isolated endophytic fungal strains may also be evaluated for their antagonistic activity against plant pathogen of the host plant.

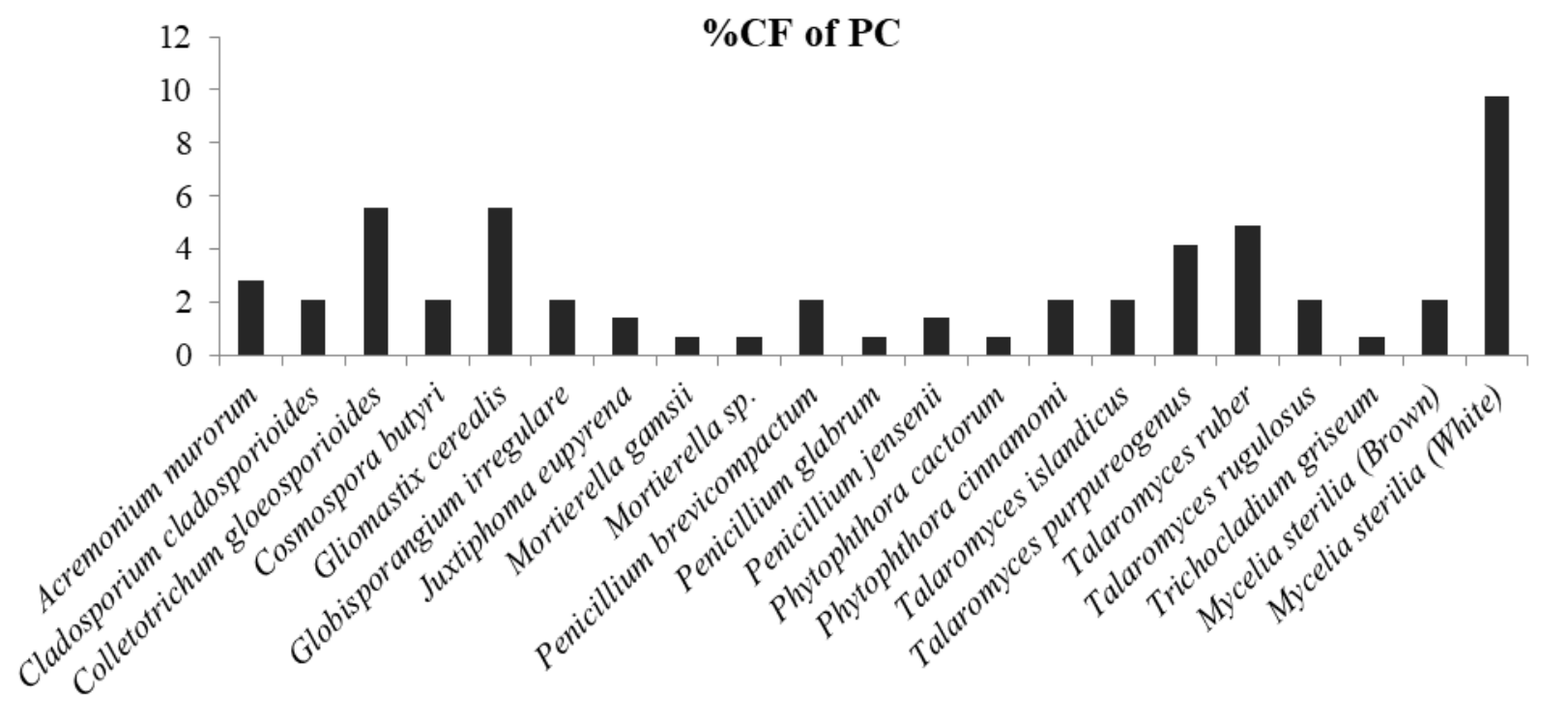

Fig. 6 - Percentage colonization frequency of endophytic fungi isolated from the pitcher cup (PC) of $N$. khasiana during the study period of 2015-2016.

\section{Acknowledgment}

The authors appreciatively acknowledge the Head of the Department, Centre for Advanced Studies in Botany, North- Eastern Hill University, Shillong for providing necessary laboratory facilities and DBT- infrastructure and CAS for providing necessary instrument facilities. The corresponding author is thankful to University Grants Commission for providing financial assistance in the form of Maulana Azad National Fellowship. Authors would like to appreciate the Head and technical staff of Institute of Advanced Study in Science and Technology (IASST), Guwahati for their help in taking SEM images.

\section{Conflict of interest}

The authors declare no conflict of interest.

\section{References}

Arnold AE, Herre EA. 2003 - Canopy cover and leaf age affect colonization by tropical fungal endophytes: ecological pattern and process in Theobroma cacao (Malvaceae). Mycologia 95, 388-398. Doi 10.1080/15572536.2004.11833083

Arnold AE, Maynard Z, Gilbert GS, Coley PD, Kursar TA. 2000 - Are tropical fungal endophytes hyperdiverse? Ecology Letters 3, 267-274. Doi 10.1046/j.1461-0248.2000.00159.x

Barnett HL, Hunter BB. 1972 - Illustrated Genera of Imperfect Fungi. 3rd ed. Burgess Publishing Company. Printed in United States of America 241

Bayman BP, Lebron LL, Tremblay RL, Lodge DJ. 1997 - Variation in endophytic fungi from roots and leaves of Lepanthes (Orchidaceae). The New Phytologist 135(1), 143-149.

Doi 10.1046/j.1469-8137.1997.00618.x

Bills GF. 1996 - Isolation and analysis of endophytic fungal communities from woody plants. In: Redlin, S.C. and Carris, L.M. (eds). Endophytic Fungi in Grasses and Woody Plants: systematics, ecology, and evolution. American Phytopathological Society Press, St Paul.

Doi 10.1023/A:1016857917950 
Bills GF, Christensen M, Powell M, Thorn G. 2004 - Saprobic soil fungi. In: Biodiversity of fungi. Inventory and Monitoring Methods. Muller, G.M., Bills, G.F. and Foster, M.S. Eds, Elsevier Academic Press, Amsterdam 271-302.

Cabral D, Stone JK, Carroll GC. 1993 - The internal mycobiota of Juncus spp: microscopic and cultural observations of infection patterns. Mycological Research 97, 367-376.

Doi 10.1016/s0953-7562(09)81140-4

Chaeprasert S, Piapukiew J, Whalley AJS, Sihanonth P. 2010 - Endophytic fungi from mangrove plant species of Thailand: their antimicrobial and anticancer potentials. Botanica Marina 53, 555-564. Doi 10.1515/bot.2010.074

Chan XY, Hong KW, Yin WF, Chan KG. 2016 - Microbiome and Biocatalytic Bacteria in Monkey Cup (Nepenthes Pitcher) Digestive Fluid. Scientific Reports 6: 20016.

Doi 10.1038/srep20016

Cosoveanu A, Sabina SR, Cabrera R. 2018 - Fungi as Endophytes in Artemisia thuscula: Juxtaposed Elements of Diversity and Phylogeny. Journal of Fungi 4, 17.

Doi 10.3390/jof 4010017

Danhorn T, Fuqua C. 2007 - Biofilm formation by plant associated bacteria. Annual Review Microbiology 61, 401-422. Doi 10.1146/annurev.micro.61.080706.093316

Domsch KH, Gams W, Anderson TH. 1980 - Compendium of soil fungi. Academic Press, London.

Ellis MB. 1976 - More Dematiaceous Hyphomycetes. Commonwealth Mycological Institute, Kew, UK.

Feller IC. 1995 - Effects of nutrient enrichment on growth and herbivory of dwarf red mangrove (Rhizophora mangle). Ecology 65, 477-505. Doi 10.2307/2963499

Fröhlich J, Hyde KD, Petrini O. 2000 - Endophytic fungi associated with palms. Mycological Research 104, 1202-1212.

Goveas SW, Madtha R, Nivas SK, D’Souza L. 2011 - Isolation of endophytic fungi from Coscinium fenestratum a red listed endangered medicinal plant. EurAsia Journal of BioSciences 5, 48-53. Doi 10.5053/ejobios.2011.5.0.6

Hammer Ø, Harper DAT, Ryan PD. 2001 - PAST: Paleontological statistics software package for education and data analysis. Palaeontologia Electronica 4, 1-9.

Hata K, Futai K. 1995 - Endophytic fungi associated with healthy pine needles and needles infested by the pine needle gall midge, Thecodiplosis japonensis. Canadian Journal of Botany 73, 384-390. Doi 10.1139/B95-040

Hata K, Tsuda M, Futai K. 1998 - Seasonal and needle age dependent changes of the endophytic mycobiota in Pinus thunbergii and Pinus densifloraneedle. Canadian Journal of Botany 76, 245-250. Doi 10.1139/B97-177

Huang WY, Cai YZ, Hyde KD, Corke H, Sun M. 2008 - Biodiversity of endophytic fungi associated with 29 traditional Chinese medicinal plants. Fungal Diversity 33, 61-75.

Jin H, Yan Z, Liu Q, Yang X et al. 2013 - Diversity and dynamics of fungal endophytes in leaves, stems and roots of Stellera chamaejasme L. in northwestern China. Antonie van Leeuwenhoek 104, 949-963.

Kobayashi DY, Palumbo JD. 2000 - Bacterial endophytes and their effects on plants and uses in agriculture. In: Bacon CW, White JF, editors. Microbial endophytes. New York (NY): Marcel Dekker

Krings M, Taylor TN, Hass H, Kerp H et al. 2007 - Fungal endophytes in a 400-million-yr-old land plant: infection pathways, spatial distribution, and host responses. New Phytology 174(3), 648-657. Doi 10.1111/j.1469-8137.2007.02008.x

Kumar DSS, Hyde KD. 2004 - Biodiversity and tissue reoccurrence of endophytic fungi from Tripterygium wilfordii. Fungal Diversity 17, 69-90.

Lacap DC, Hyde KD, Liew ECY. 2003 - An evaluation of the fungal 'morphotype' concept based on ribosomal DNA sequences. Fungal Diversity 12, 53-66.

Maheswari S. 2011 - Biodiversity of endophytic fungi associated with Ficus religiosa and F. bengholensis. Mycologia Balcanica 8, 169-172. 
McCully ME. 2001 - Niches for bacterial endophytes in crop plants: a plant biologist's view. Australian Journal of plant Physiology 28, 983-990. Doi 10.1071/PP01101

Peláez F, Platas G, Collado J, Díez MT. 1996 - Infraspecific variation in two species of aquatic hyphomycetes assessed by RAPD analysis. Mycological Research 100, 831-837.

Peters AF. 1991 - Field and culture studies of Streblonema macrocystis sp. nov. (Ectocarpales, Phaeophyceae) from Chile, a sexual endophyte of giant kelp. Phycologia 30, 365-377.

Doi 10.2216/i0031-8884-30-4-365.1

Petrini O. 1991 - Microbial Ecology of Leaves. New York: Springer Verlag 179-97. Doi 10.12691/jaem-4-5-2

Pielou EC. 1995 - Biodiversity versus old-style diversity: measuring biodiversity for conservation. Measuring and Monitoring Biodiversity in Tropical and Temperate Forests (eds T.J.B. Boyle \& B. Boontawee) 19-46. CIFOR, Bogor, Indonesia.

Rajagopal K. 1999 - Biology and Ecology of endophytic fungi from tropical trees with special reference to neem (Azadirachta indica, A.Juss). Ph.D Thesis University of Madras.

Raviraja NS. 2005 - Fungal endophytes in five medicinal plants species from Kudramukh Range, Western Ghats of India. Journal of Basic Microbiology 45, 230-235.

Doi 10.1002/jobm.200410514

Schulz B, Boyle C. 2006 - What are endophytes? In Microbial root endophytes. BJE Schulz, CJC Boyle, and TN Sieber (eds). Berlin: Springer 1-13.

Schulz B, Wanke U, Draeger S, Aust HJ. 1993 - Endophytes from herbaceous plants and shrubs: effectiveness of surface sterilization methods. Mycological Research 97, 1447-1450. Doi 10.1016/s0953-7562(09)80215-3

Shannon CE, Weaver W. 1949 - The Mathematical Theory of Communication, Urbana: University of Illinois Press.

Simpson EH. 1951 - The Interpretation of Interaction in Contingency Tables. Journal of the Royal Statistical Society 13, 238-241.

Siqueira VM, Conti R, Araújo JM, Souza-Motta CM. 2011 - Endophytic fungi from the medicinal plant Lippia sidoides Cham. and their antimicrobial activity. Symbiosis 53, 89-95.

Doi 10.1007/s13199-011-0113-7

Stone JK, Bacon W, White JF. 2002 - An overview of endophytic microbes: endophytism defined. Bacon, C.W. and White, J.F. (Eds.). Microbial endophytes, Dekker, New York.

Sturz AV, Nowak J. 2000 - Endophytic communities of rhizobacteria and the strategies required to create yield enhancing associations with crops. Applied Soil Ecology 15, 183-190.

Doi 10.1016/S0929-1393(00)00094-9

Subramanian CV. 1971 - Hyphomycetes: an account of Indian species, except Cercosporae. Indian Council of Agricultural Research, New Dehli.

Sun JQ, Guo LD, Zang W, Ping WX, Chi DF. 2008 - Diversity and ecological distribution of endophytic fungi associated with medicinal plants. Science China Series C-Life Sciences 51(8), 751-759. Doi 10.1007/s11427-008-0091-z

Suryanarayanan TS, Kumaresan V, Johnson JA. 1998 - Foliar fungal endophytes from two species of the mangrove Rhizophora. Canadian Journal of Microbiology 44, 1003-1006.

Suwannarach N, Bussaban B, Nuangmek W, McKenzie EHC et al. 2011 - Diversity of Endophytic Fungi Associated with Cinnamomum bejolghota (Lauraceae) in Northern Thailand. Chiang Mai Journal of Science 39(3).

Tan HM, Coa LX, He ZF, Su JG et al. 2006 - Isolation of endophytic actinomycetes from selected plants and their antifungal activity. World Journal of Microbiology and Biotechnology 22, $1275-1280$.

Tayung K, Jha DK. 2006 - Antimicrobial evaluation of some fungal endophytes isolated from bark of Himalayan yew. World Journal of Agricultural Sciences 2, 489-494.

Thalavaipandian A, Ramesh V, Bagyalakshmi, Muthuramkumar S, Rajendran A. 2011 - Diversity of fungal endophytes in medicinal plants of courtallam hills, Western Ghats, India. Mycosphere 2(5), 575-582. Doi 10.5943/mycosphere/2/5/7 
Toofanee SB, Dulymamode R. 2002 - Fungal endophytes associated with Cordemoya integrifolia. Fungal Diversity 11, 169-175.

Xing XK, Chen J, Xu MJ, Lin WH, Guo SX. 2011 - Fungal endophytes associated with Sonneratia (Sonneratiaceae) mangrove plants on the south coast of China. Forest Patholog, 41, 334-340. Doi 10.1111/j.1439-0329.2010.00683.x 